\title{
Ammonium Adsorption Onto a Contaminated Soil-Water Environment Amended with Organic Matter
}

\author{
Rasha Al-Saedi i*, Zaman Ageel Hammood', Tasnim Fahim Chyad ${ }^{1}$ \\ 1 Department of Environmental Engineering, College of Engineering, Mustansiriyah University, Baghdad, Iraq \\ *Corresponding author's e-mail: rasha.az2013@gmail.com, rasha.azeez@uomustansiriyah.edu.iq
}

\begin{abstract}
In this research, the ability of calcareous soil to absorb ammonium was investigated and the effect of compost amendment as a natural organic source on ammonium adsorption was also studied. The $\mathrm{pH}$, dissolved ammonium concentrations, ammonium adsorption capacity, and cation exchangeable capacity for the soil samples were analyzed in relation to an untreated control and treatment with compost under ambient temperature and different initial ammonium concentrations $(10,20,30,40,50,70$, and $100 \mathrm{mg} / \mathrm{L})$. The amounts of ammonium adsorbed increased along with initial concentrations of dissolved ammonium for control and treatment with compost. The models evaluated in this study included the Langmuir and Freundlich isotherms. Ammonium adsorption was found to conform to the Freundlich equation isotherm more than that with Langmuir. The highest adsorption capacity was exhibited by $100 \mathrm{mg} / \mathrm{L}$ added initial ammonium concentration. Adding compost as a source of organic matter enhanced the adsorption capacity of calcareous soil with an increase in the adsorption of $36 \%$, which indicated that the organic matter is a key limiting parameter in the mechanism of ammonium adsorption. Ammonium adsorption by calcareous soils is an important process in identifying the ammonium nitrogen route in soil-water systems.
\end{abstract}

Keywords: ammonium, adsorption, calcareous soil, compost, cation exchange capacity.

\section{INTRODUCTION}

The inorganic nitrogen $(\mathrm{N})$ species, which included nitrate $\left(\mathrm{NO}_{3}\right)$, nitrite $\left(\mathrm{NO}_{2}\right)$ and ammonia $\left(\mathrm{NH}_{3}\right)$ or ammonium $\left(\mathrm{NH}_{4}\right)$, have a considerable effect on aquatic environments, such as eutrophication of receiving water bodies, an extensive decline in the level of dissolved oxygen, due to the instant availability of these dissolved $\mathrm{N}$ species for uptake by microorganisms (Zhu et al., 2011). Ammonium is a prevalent $\mathrm{N}$ subsurface pollutant, which emerges from different sources, such as landfill sites, industrial polluted areas, sewage systems, wastewater, and fertilizers (Ranjbar and Jalali, 2013). The concentrations of ammonium might exceed the standard limits of disposal to waterbodies (Zhu et al., 2011), with high concentrations hindering the decomposition of organic matter via microorganisms (Ranjbar and Jalali, 2013).

The three major routes of $\mathrm{NH}_{4}$ removal in the ecosystems are mainly nitrification, assimilation into microbial cells, and adsorption onto substrate media (Sun et al., 2005; Tyrrel et al., 2002). The nitrification process is influenced by some environmental parameters such as, level of $\mathrm{N}$ and degree of temperature (Zhu et al., 2011). Assimilation into microbial cells is worth calculating when there is a source of organic matter, because large amounts of $\mathrm{N}$ are removed during microorganism growth and respiration (Sun et al., 2005). Thus, this study focused only on the mechanism of ammonium adsorption onto the substrate medium.

Calcareous soils have been used as substrates in different land-based wastewater treatment systems including, wetlands, grasslands, farmland, and over land flow treatment systems (Van Hoewyk et al., 2000; Tyrrel et al., 2002), due to their ability to fix the ammonium added (Avinmelch and Leher, 1977; Juang et al, 2001). Several factors are of significance for the capacity of soils to absorb ammonium, such as, $\mathrm{pH}$, temperature, cation exchange capacity (CEC), drying and wetting of soils, amount and concentration of ammonium, particle size, organic matter, 
and the solubility of the potential reaction products (Avinmelch and Leher, 1977, Nommik and Vahtras, 1982; Clemente and Bernal, 2006).

Hinman, (1966); Porter and Stewart, (1970); and Zhu et al., (2011) found that the treatment of soils with organic matter generally caused a significant reduction in the ammonium adsorption. In contrast, some studies reported that ammonium adsorption correlated positively with the organic matter content in soils (Rosenfeld, 1979; Boatman and Murray, 1982; Ranjbar and Jalali, 2013). Compost is an organic amendment, which is commonly used to adjust the physical, chemical, and biological characteristics of soils (Hebert et al., 1991). Some studies have demonstrated the role of calcareous soil in ammonium adsorption without considering any additions (Juang et al, 2001; Ranjbar and Jalali, 2013). A study conducted by Clemente and Bernal, (2006) investigated the effect of compost on OM mineralization and fractionation of heavy metals in calcareous soils. However, there is a paucity of information on whether adding compost to the main soil media can further enhance adsorption. Thus, the first aim of this experiment was to further investigate the relationship between ammonium adsorption efficiency and organic matter amendment in calcareous soil.

In wet mineral soil systems, the mechanism of ammonium adsorption is an irreversible adsorption of cation exchange sites. Some researchers found a positive correlation between the amount of $\mathrm{NH}_{4}$ adsorbed and CEC (Zhang et al., 2007; $\mathrm{Yu}$ et al., 2011; Zhu et al., 2011, and Ranjbar and Jalali, 2013). In contrast, other researchers have reported no relation between the amount adsorbed and the changes in CEC (Page et al., 1967). However, the research on the effect of cation exchange capacity on the $\mathrm{NH}_{4}$ adsorption in soils is still limited (Buss et al., 2004). Therefore, the second aim was to highlight the effect of the significant influencing parameter on ammonium adsorption, which is CEC.

\section{MATERIALS AND METHODS}

\section{Experimental sampling}

Surface calcareous soil $(0-30 \mathrm{~cm})$, collected from an agriculture farm in Baghdad, was used in this study. The properties of the soil used in this experiment are presented in Table 1.
Table 1. Chemical and physical properties of the soil tested and organic amendment

\begin{tabular}{|l|c|c|}
\hline \multicolumn{1}{|c|}{ Characteristics } & Soil & Soil + 3\% compost \\
\hline Texture & Clay loam & - \\
\hline Clay $(\%)$ & 39 & - \\
\hline Sand $(\%)$ & 21 & - \\
\hline Silt $(\%)$ & 40 & - \\
\hline $\mathrm{pH}$ & 7.2 & 7.4 \\
\hline $\mathrm{CaCO}_{3}(\%)$ & 23 & 12 \\
\hline $\mathrm{CEC}(\mathrm{meq} / 100 \mathrm{gm})$ & 10.4 & 13.9 \\
\hline $\left.\mathrm{OM}^{\prime} \%\right)$ & 0.84 & 3 \\
\hline $\mathrm{NH}_{4}-\mathrm{N}(\mathrm{mg} / \mathrm{L})$ & 1.23 & 10.5 \\
\hline $\mathrm{Mg}^{+2}(\mathrm{meq} / 100 \mathrm{gm})$ & 3.02 & 4.03 \\
\hline $\mathrm{Ca}^{+2}(\mathrm{meq} / 100 \mathrm{gm})$ & 6.3 & 8.34 \\
\hline $\mathrm{Na}^{+}(\mathrm{meq} / 100 \mathrm{gm})$ & 0.63 & 0.83 \\
\hline $\mathrm{K}^{+}(\mathrm{meq} / 100 \mathrm{gm})$ & 0.52 & 0.7 \\
\hline
\end{tabular}

For the purpose of ammonium adsorption, the soil was air dried, passed through a $1 \mathrm{~mm}$ sieve, and thoroughly mixed. Then, $20 \mathrm{~mL}$ of $1 \mathrm{~N} \mathrm{NH}_{4} \mathrm{Cl}$ was added to $3 \mathrm{gm}$ of soil samples in a centrifuge tubes (in triplicate) under different initial ammonium concentrations $(10,20,30,40$, $50,70$, and $100 \mathrm{mg} / \mathrm{L})$. The samples were then shaken for 48 hours at ambient temperature with a speed of $180 \mathrm{r} / \mathrm{min}$. The supernatants from the samples were filtered through $0.45 \mu \mathrm{m}$ membrane filters and analyzed for the $\mathrm{NH}_{4}$ content. The $\mathrm{NH}_{4}$ content was determined using the Kjeldahl method (Bremner and Breitenbeck, 1983). The amount of ammonium adsorbed was then calculated from (Sung et al., 2014):

$$
\text { Adsorption capacity }=\left(C_{i}-C_{f}\right) \times(V / W)
$$

where: $C_{i}$ and $C_{f}$ - the initial and the final concentrations $(\mathrm{mg} / \mathrm{L})$ respectively, $V$ - the volume of sample (L), $W$ - the adsorbent weight (g).

In order to determine if the ammonium adsorption by organic matter was effective, the soil samples were treated with $3 \%$ compost (dry weight of soil basis) prior to the addition of $\mathrm{NH}_{4} \mathrm{Cl}$ and then the same procedure of ammonium adsorption protocol was followed. All the treatments were replicated three times.

\section{Analytical measurements}

In relation to the measurements of the initial physical and chemical soil characteristics, the OM content was determined using the loss on 
ignition method (Nelson and Sommer, 1996). The texture of soil was determined using the hydrometer method (Hunt and Gilkes, 1992). $\mathrm{CaCO}_{3}(\%)$ was determined using the dry combustion method (Nelson and Sommer, 1996). $\mathrm{Mg}^{+2}, \mathrm{Ca}^{+2}, \mathrm{Na}^{+}, \mathrm{K}^{+}$ were measured using the Barium Chloride method (Ciesielski and Sterckeman, 1997).

The soil $\mathrm{pH}$ was determined in a 1:10 soil to water suspension. The CEC test was performed using the Barium Chloride method (Ciesielski and Sterckeman, 1997). All the tests were performed in triplicate.

\section{RESULTS}

At the beginning of the experiment, the average $\mathrm{pH}$ level of soil mixed with ammonium solution $(\mathrm{CON})$ was 7.22 , raising to 7.80 at the end of the experiment. Table 2 shows that $\mathrm{pH}$ increased with increasing $\mathrm{NH}_{4}$ adsorption, which was in accordance with the findings showed by (Nommik and Vahtras, 1982). After compost addition (CON+COMP), the $\mathrm{pH}$ level was initially 7.38, changing to 7.91 at the end of the experiment.

The $\mathrm{NH}_{4}$ adsorptions $\left(q_{e}\right)$ by calcareous soil for CON and $3 \%$ compost (CON+COMP) treatments with initial ammonium concentrations ranging from 10 to $100 \mathrm{mg} / \mathrm{L}$ are presented in Figure 1. We shows that the amount of ammonium adsorption enhanced as the amount of ammonium applied increased in both treatments, with the greatest adsorption capacities of 25.1 and $39.4 \mathrm{mg} / \mathrm{kg}$ for $\mathrm{CON}$ and CON+COMP, respectively, at a maximum applied ammonium concentration of $100 \mathrm{mg} / \mathrm{L}$.

The CEC values for $\mathrm{CON}$ and $\mathrm{CON}+\mathrm{COMP}$ ranged from 10.9 to 13.2 and 14.2 to $42.7 \mathrm{meq} / 100$ gm, respectively, over the experimental period. Figure 2 shows a positive correlation trend between the magnitude of ammonium adsorption and CEC in both cases. It can be seen that both treatments had a linear trend, but the trend was sharper with compost addition than the control

Table 2. $\mathrm{pH}$ levels in relation to ammonium adsorption capacities for both treatments

\begin{tabular}{|c|c|c|c|}
\hline \multicolumn{2}{|c|}{ CON } & \multicolumn{2}{c|}{ CON+COMP } \\
\hline $\mathrm{NH}_{4}$ adsorbed $q_{\mathrm{e}}(\mathrm{gm} / \mathrm{kg})$ & $\mathrm{pH} \pm 0.08$ & $\mathrm{NH}_{4}$ adsorbed $q_{\mathrm{e}}(\mathrm{gm} / \mathrm{kg})$ & $\mathrm{pH} \pm 0.074$ \\
\hline 2.1 & 7.22 & 4.5 & 7.38 \\
\hline 3.6 & 7.30 & 9.5 & 7.42 \\
\hline 5.8 & 7.41 & 12.9 & 7.49 \\
\hline 6.3 & 7.47 & 18.3 & 7.54 \\
\hline 11.2 & 7.59 & 22.4 & 7.66 \\
\hline 14.2 & 7.71 & 30.8 & 7.91 \\
\hline 25.1 & 7.80 & 39.4 & 78 \\
\hline
\end{tabular}

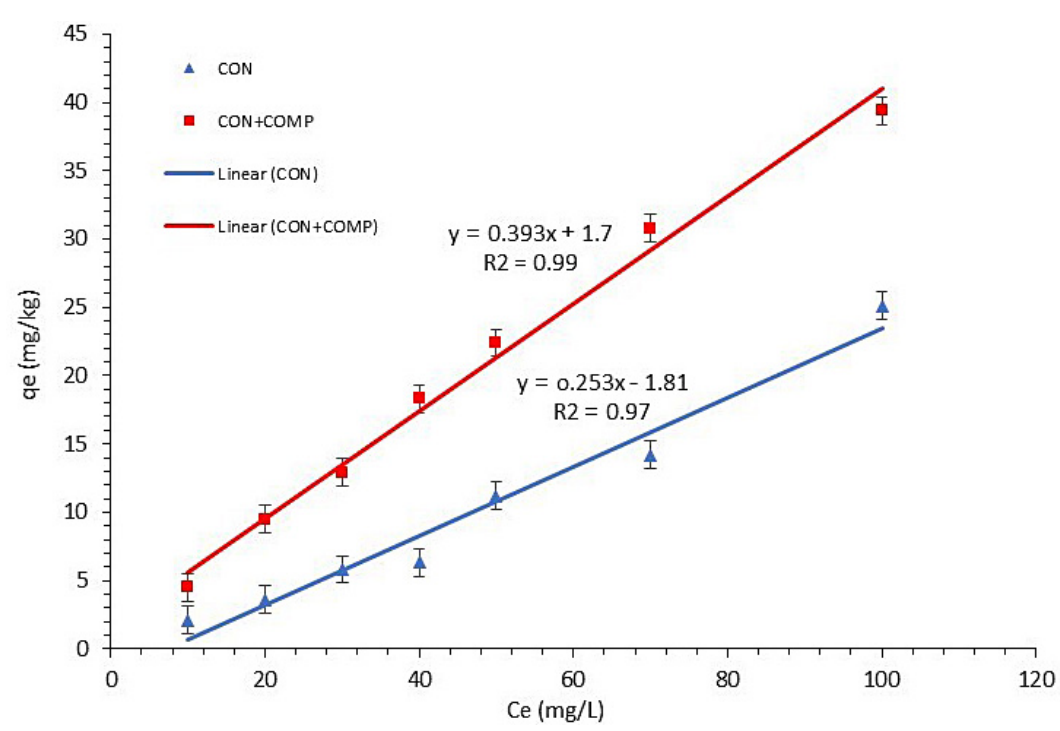

Figure 1. Relationship between initial ammonium concentrations and ammonium adsorption capacity ( $\mathrm{Se}=3.01$ and 4.63 for $\mathrm{CON}$ and $\mathrm{CON}+\mathrm{COMP}$ respectively) 


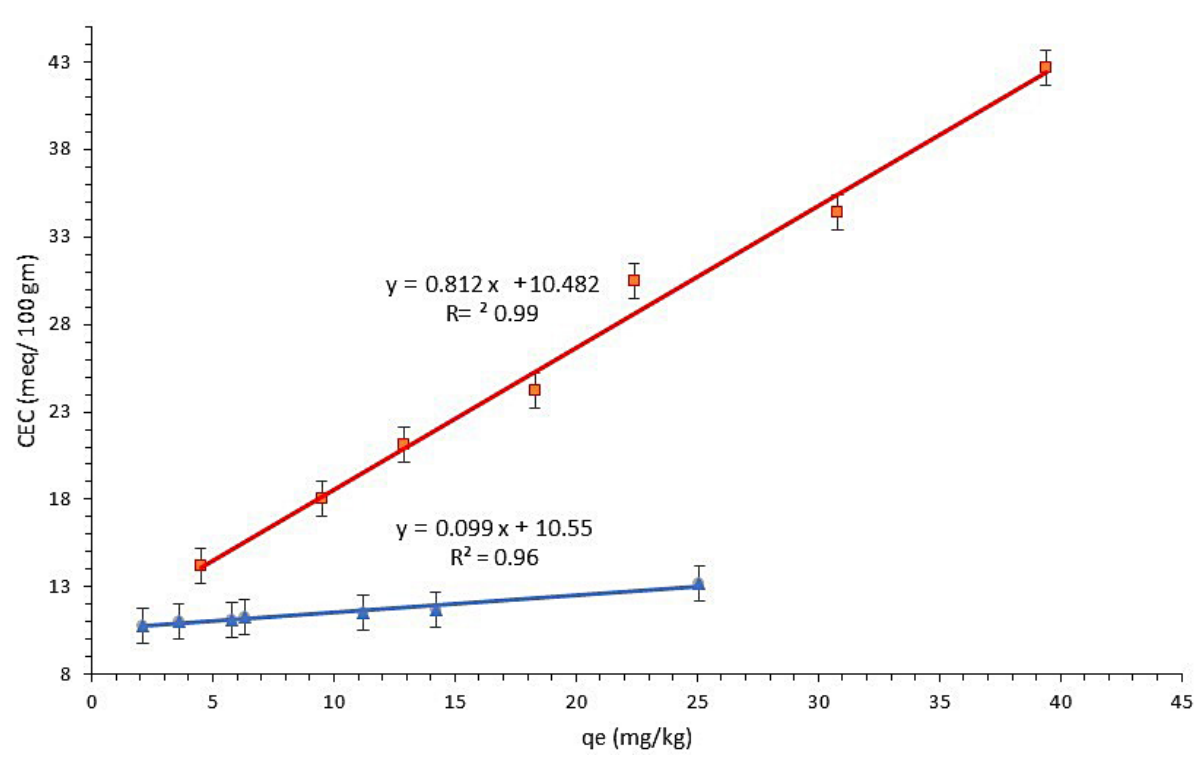

Figure 2. Relationship between ammonium adsorption capacity and CEC $(\mathrm{Se}=0.303$ and 3.78 for $\mathrm{CON}$ and $\mathrm{CON}+\mathrm{COMP}$ respectively)

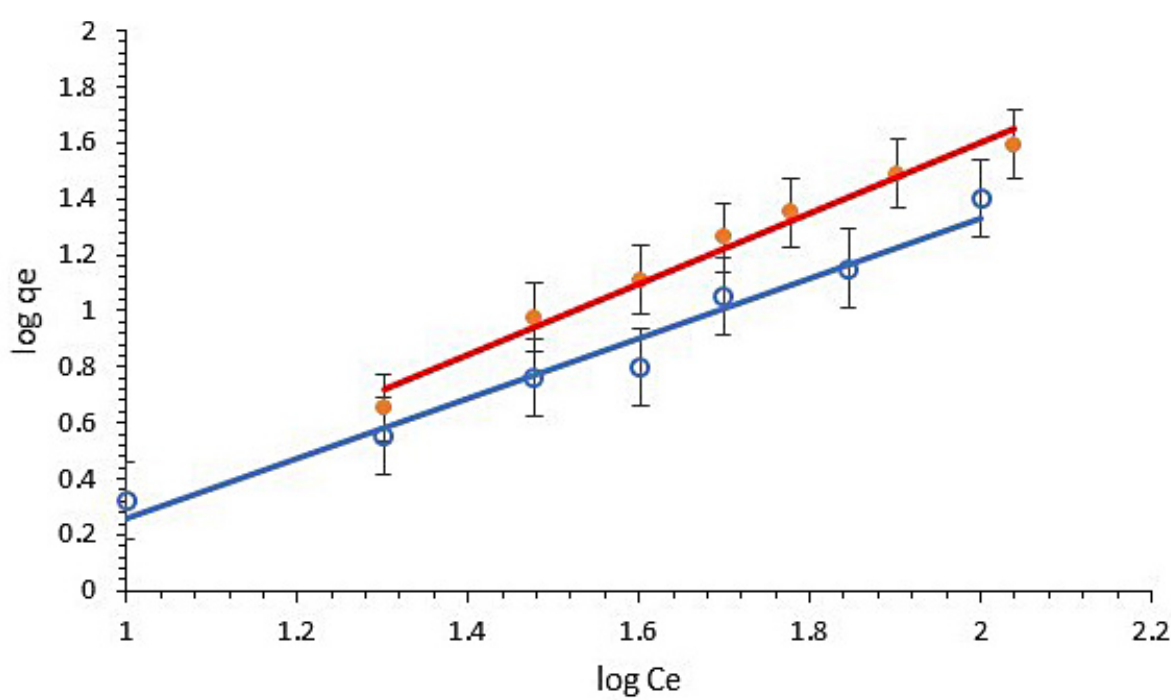

Figure 3. Freundlich isotherm for ammonium adsorption by control and compost amendment $(\mathrm{Se}=0.139$ and 0.122 for $\mathrm{CON}$ and $\mathrm{CON}+\mathrm{COMP})$

treatment. Compost treatment had a significantly higher treatment than control.

In relation to the adsorption capacity, we tested two adsorption isotherm equations (Langmuir and Freundlich).

The Langmuir isotherm can be written as (Ranjbar and Jalali, 2013)

$$
C_{e} / q_{e}=1 / k_{1} k_{2}+1 / k_{1} C_{e}
$$

where: $k_{1}$ and $k_{2}$ are constants.

The linear form of the Freundlich isotherm is given as (Ranjbar and Jalali, 2013)

$$
q_{e}=K C_{e}{ }^{\mathrm{b}}
$$

where: $K$ and $b$ are empirical constants.
Applying $\mathrm{NH}_{4}$ adsorption data to these two isotherms, adsorption of ammonium by both treatments was estimated. However, it was found that only the Freundlich equation successfully described the ammonium adsorption over an initial concentration range of 10 to $100 \mathrm{mg} / \mathrm{L} \mathrm{NH}_{4}$. Table 3 and Figure 3 show the constants and regression coefficients of the Freundlich isotherm. The Freundlich $\mathrm{K}$ and $\mathrm{b}$ were evaluated empirically for both treatments. It has been stated that $\mathrm{K}$ can be related to the adsorption capacity of the soil. The Freundlich $\mathrm{K}$ value for control was smaller than the compost treatment, which strongly suggests that the total adsorption capacity of compost 
Table 3. Freundlich constants and correlation coefficients for ammonium sorption by control and compost amendment

\begin{tabular}{|c|c|c|c|c|c|}
\hline \multicolumn{3}{|c|}{ CON } & \multicolumn{3}{c|}{ CON+COMP } \\
\hline$K$ & $b$ & $R^{2}$ & $K$ & $b$ & $R^{2}$ \\
\hline 0.810 & 1.072 & 0.973 & 0.933 & 1.268 & 0.981 \\
\hline
\end{tabular}

in calcareous soil was much higher than that of control. This maybe due to the enrichment of organic matter that could enhance the adsorption process (Rosenfeld, 1979; Boatman and Murray, 1982; Ranjbar and Jalali, 2013).

\section{DISCUSSION}

Our results indicated a positive correlation between ammonium adsorption and $\mathrm{pH}$, which was in accordance with Murray et al., (1978), who confirmed a positive relation between ammonium adsorption and alkalinity.

Ammonium chloride reacts with calcareous soils to produce a $\mathrm{CaCl}_{2}$ precipitate and $\left(\mathrm{NH}_{4}\right)_{2} \mathrm{CO}_{3}$. The completeness of this precipitation reaction would depend on the water content of the soil. As the soil water content increases, more $\mathrm{CaCl}_{2}$ dissolves. In this research, the water content of the soil samples was $70 \%$. The reaction of $\mathrm{NH}_{4} \mathrm{Cl}_{2}$ with $\mathrm{CaCO}_{3}$, therefore, is driven less towards the formation of $\left(\mathrm{NH}_{4}\right)_{2} \mathrm{CO}_{3}$. The soil $\mathrm{pH}$ increased slowly after the application of $\mathrm{NH}_{4} \mathrm{Cl}_{2}$ (Table 1). The source of $\mathrm{OH}^{-}$is again the decomposition of $\left(\mathrm{NH}_{4}\right)_{2} \mathrm{CO}_{3}$ (Fenn and Kissel, 1973)

When compost was added, the positive relationship between ammonium and $\mathrm{pH}$ kept the same with a slight increase in the $\mathrm{pH}$ levels, However, when the soil $\mathrm{pH}$ originally has a value of around 7, adding soil amendment such as compost (particularly with little amount) will not affect the soil $\mathrm{pH}$ (Clemente and Bernal, 2006). Furthermore, the adsorption mechanism seemingly performs better with stable $\mathrm{pH}$ of soil (Fenn and Kissel, 1973)

The ammonium- chloride application changed the soil $\mathrm{pH}$ only slightly from the initial value of 7.22. The chloride was not precipitated too much; therefore, a slight increase occurred in the $\mathrm{pH}$ level, and $\mathrm{NH}_{4}$ adsorption was much promoted (Fenn and Kissel, 1973)

The solubility of the potential reaction product (ammonium salt added) was the major factor regulating ammonium adsorption in calcareous soil (Ranjbar and Jalali, 2013). When an ammonium salt $\left(\mathrm{NH}_{4} \mathrm{CL}\right)$ dissolves in a calcareous soil, the salt produces a high ammonium $\left(\mathrm{NH}_{4}\right)$ adsorption. These ammonium anions (such as $\mathrm{CL}^{-}$) react with $\mathrm{Ca}^{+2}$ in the soil to form precipitates, which is highly soluble. The rate of ammonium adsorption increased along with the solubility of the precipitate, because soluble reaction products were formed (Fenn and Kissel, 1973).

In fact, the ion exchange capacity of $\mathrm{NH}_{4}$ varies based on the initial $\mathrm{NH}_{4}$ concentration and the availability of other cations in the solid-solution phases (Ranjbar and Jalali, 2013).

Our results were similar to (Kimothe et al., 1998) and (Nommik and Vahtras, 1982), who observed enhancement in the amount of ammonium adsorbed as the initial ammonium concentration increased (Juang et al., 2001). This is due to a complete removal of the prevalent cations by the $\mathrm{NH}_{4}$ ions (Ranjbar and Jalali, 2013). Ranjbar and Jalali, (2013) indicated that soil with positive charges can absorb the majority of the applied $\mathrm{NH}_{4}$ solution. This coincided with the characteristics of the soil used in this experiment, which holds many positive cations.

Ammonium adsorption is the ion exchange of the $\mathrm{NH}_{4}$ ions with sodium, potassium, magnesium, and calcium at cation exchange sites (Ranjbar and Jalali, 2013). $\mathrm{NH}_{4}$ occupy the maximum amount of exchange sites that can possibly be provided by CEC (Matschonat and Matzner, 1996). When the concentration of exchangeable $\mathrm{NH}_{4}$ exceeds the equilibrium value in the soil, $\mathrm{NH}_{4}$ adsorption occurs (Nommik and Vahtras, 1982). $\mathrm{Ca}^{+2}$ is the prevalent cation in natural calcareous soils, and it is preferably adsorbed in most soils over $\mathrm{Mg}^{+}$and monovalent cations (Fleisher et al., 1987).

Rosenfeld, (1979) reported that ammonium is adsorbed not only by clay minerals but also by organic matter. Therefore, compost as an organic carbon was added to the soil samples. As $\mathrm{N}$ is usually stored in the soil as an organic form, compost stabilizes the $\mathrm{N}$ compounds in soils (Nevens and Reheul, 2003).

Hinman, (1966); Porter and Stewart, (1970); Zhu et al., (2011) found that the treatment of soils with organic matter caused generally a significant 
reduction in the ammonium adsorption. In contrast, some studies reported that the ammonium adsorption correlated positively with the organic matter content in soils (Rosenfeld, 1979; Boatman and Murray, 1982; Ranjbar and Jalali, 2013).

Rosenfeld, (1979) indicated that exchangeable $\mathrm{NH}_{4}^{+}$often relates to the organic matter content. This was also confirmed by Boatman and Murray, (1982) who studied the ammonium adsorption on marine sediments. He found that the organic matter enriched sediments, clay-organic matter complex controlled the $\mathrm{NH}_{4}$ sorption. His findings confirmed that the sediments poor with organic matter influenced the behavior of the ammonium adsorption.

The total amount of positive charges that the soil can absorb is called the cation exchange capacity (CEC). CEC impacts how quickly nutrients move through the profile. A soil with a low CEC is much less fertile because it cannot hold on too many nutrients, and they usually contain less clays as well as less able to hold spilt chemicals (CUCE, 2007)

Our results showed a positive correlation between ammonium adsorbed and CEC, which was in accordance with (Ranjbar and Jalali, 2013), who investigated the adsorption of ammonium in agricultural calcareous soil. Their data indicated a positive relationship between ammonium adsorption and CEC under initial ammonium concentrations ranging from (10 to $150 \mathrm{mg} / \mathrm{L}$ ). This was also in agreement with Zhang et al., (2007); Yu et al., (2011); and Zhu et al., (2011). Zhu et al., (2011), who reported a positive correlation between the ammonium adsorption and CEC.

\section{CONCLUSIONS}

Adding compost does not significantly affect the quantity of precipitates formed, as there was a slight increase in the $\mathrm{pH}$ levels. Compost can be useful for the adsorption of ammonium in calcareous soils. However, the interest of using compost may varied depending on the ecological benefits.

The present investigation showed that ammonium was adsorbed more in the ammonium contaminated soil treated with compost than in the CONT, due to the enhancement of the exchange process after the organic matter amendment. Therefore, it can be concluded that the cation exchange process was the major mechanism influencing the ammonium adsorption in the calcareous soil treated with compost.
The results presented demonstrate that for the calcareous soils, CEC enhanced with the amount of ammonium adsorbed. It can be inferred that the correlation between $\mathrm{NH}_{4}$ adsorbed and CEC was highly greater with the compost treatment than control, resulting in a somewhat different linear trend. Therefore, there is a need to expand the research undertaken here to better define the role of compost of different concentrations (lower and higher than the investigated ratio) on CEC in a saturated calcareous soil.

The conclusions drawn indicated that CEC is a reliable parameter for determining the amount of the adsorbed ammonium by an ion exchange process. Moreover, understanding the adsorption behavior of ammonium in the soil water environment is priceless for the knowledge of $\mathrm{N}$ chemistry in soils.

\section{Acknowledgement}

The authors would like to thank Mustansiriyah University (www.uomustansiriyah.edu.iq) Baghdad, Iraq for its support in the present work.

\section{REFERENCES}

1. Avnimelech Y. and Laher M. 1977. Ammonia volatilization from soils: Equilibrium considerations. Soil Sci. Soc. Am. J. 41: 1080-84. doi.org/10.2136/ sssaj1977.03615995004100060013x

2. Boatman, C. D., \& Murray, J. W. 1982. Modeling exchangeable $\mathrm{NH}_{4}^{+}$adsorption in marine sediments: process and controls of adsorption. Limnol Oceanogr. 27: 99-110. doi.org/10.4319/1o.1982.27.1.0099

3. Bremner JM, Breitenbeck GA. 1983. A simple method for determination of ammonium in semimicro-Kjeldahl analysis of soils and plant materials using a block digester. Commun Soil Sci Plant Anal. 14: 905-913. doi.org/10.1080/00103628309367418

4. Buss, S. R., Herbert, A. W., Morgan, P., Thornton, S. F., \& Smith, W. N. 2004. A review of ammonium attenuation in soil and groundwater. Q. J. Eng. Geol. 37: 347-359. doi.org/10.1144/1470-9236/04-005

5. Clemente R, Bernal MP. 2006. Fractionation of heavy metals and distribution of organic carbon in two contaminated soils amended with humic acids. Chemosphere. 64: 1264-1273. doi.org/10.1016/j. chemosphere.2005.12.058

6. Cornell University Cooperative Extension (CUCE). 2007. Cation Exchange Capacity, Agronomy Fact Sheet, Series\#22. Department of Crop and Soil Sciences, College of Agriculture and Life Sciences, 
Cornell University.

7. Ciesielski, H. \& Sterckeman, T. 1997. A comparison between three methods for determination of cation exchange capacity and exchangeable cations in soils, Agronomie. 17: 9-16.

8. Fenn L B and Kissel D E 1973 Ammonia volatilization from surface applications of ammonium compounds on calcareous soils. I. General theory. Soil Sci. Soc. Am. Proc. 37: 855-859. doi.org/10.2136/ sssaj1973.03615995003700060020x

9. Fleisher Z, Kenig A, Ravina I \& Hagin J (1987) Model of ammonia for the determination of cation exchange capacity and exchangeable cations sorption in forest soils Z. Pflanzenernahrung Bodenkunde. 159: 505-11.

10. Hebert K, Karam A, Parent LE 1991 Mineralization of nitrogen and carbon in soils amended with composted manure. Biol. Agric. Hort. 7: 336-361. doi.org/10.1080/01448765.1991.9754565

11. Hinman WC (1966) Ammonium fixation in relation to exchangeable $\mathrm{K}$ and organic matter content in two Saskatchewan soils. Can J Soil Sci 46: 223-225. doi. org/10.4141/cjss66-036

12. Hunt, N., Gilkes, R., 1992. Farm Monitoring Handbook. A Practical Down-toearth Manual for Farmers and Other Land Users. University of Western Australia, Nedlands, WA, and Land Management Society: Como, WA.

13. Juang TC, Wang MK, Chen HJ, Tan CC. 2001. Ammonium fixation by surface soils and clays. Soil Sci. 166: 345-352.

14. Kithome M, Paul J W, Lavkulich L M and Bomke A A. 1998. Kinetics of ammonium adsorption and desorption by the natural zeolite clinoptilolite. Soil Sci. Soc. Am. J. 62: 622-629. doi.org/10.2136/ sssaj1998.03615995006200030011x

15. Matschonat Gand Matzner E. 1996. Soil chemical properties affecting $\mathrm{NH}_{4}^{+}$volatilization from calcareous soils. Plant Soil. 103: 205-212.

16. Murray, J. W., Grundmanis, V., \& Smethie, W. M. 1978. Interstitial water chemistry in the sediments of Saanich Inlet. Gcochimica et Cosmochimica Acta. 42: 1011-1026.

17. Nelson, D.W. and Sommers, L.E. 1996. Total carbon, organic carbon, and organic matter. In Methods of Soil Analysis. Part 3. Chemical Methods, Sparks, D.L., ed., SSSA Book Series No. 5, Soil Science Society of America: Madison, Wisconsin. doi.org/10.2136/sssabookser5.3.c34

18. Nevens F., Reheul D. 2003. The application of vegetable, fruit and garden waste (VFG) compost in addition to cattle slurry in a silage maize monoculture: nitrogen availability and use, Eur. J. Agron. 19:
189-203. doi.org/10.1016/S1161-0301(02)00036-9

19. Nommik, H. \& Vahtras, K. 1982. Retention and fixation of ammonium and ammonia in soils. Agron Monogr. 22: 123-171. doi.org/10.2134/agronmonogr22.c4

20. Page AL, Burge WD, Ganje TJ, Garber MJ. 1967. Potassium and ammonium fixation by vermiculitic soils. Soil Sci Soc Am J 31: 337-341. doi. org/10.2136/sssaj1967.03615995003100030016x

21. Porter LK, Stewart BA. 1970. Organic interferences in the fixation of ammonium by soils and clay minerals. Soil Sci. 109: 229-233.

22. Ranjbar F, Jalali M. 2013. Measuring and modeling ammonium adsorption by calcareous soils. Environ. Monit. Asses. 185: 3191-3199. doi.org/10.1007/ s10661-012-2782-y

23. Rosenfeld, J. K. 1979. Ammonium adsorption in nearshore anoxic sediments. Limnol. Oceanogr. 24: 356-364. doi.org/10.4319/1o.1979.24.2.0356

24. Sun, Zhao, Allen, 2005. Enhanced removal of organic matter and ammoniacal-nitrogen in a column experiment of tidal flow constructed wetland system. J. Biotechnol. 115: 189-197. doi.org/10.1016/j. jbiotec.2004.08.009

25. Sung, W.P., Kao, J.C.M., Chen, R. 2014. Environment, Energy and Sustainable Development, first ed. CRC Press, Leiden, The Netherlands.

26. Tyrrel, S.F., Harrison, P.B.L., Harrison, K.S. 2002. Removal of ammoniacal nitrogen from landfill leachate by irrigation onto vegetated treatment planes. Water Res. 36: 291-299. doi.org/10.1016/ S0043-1354(01)00217-2

27. Van Hoewyk D, Groffman PM, Kiviat E, Mihocko G, Stevens G. 2000. Soil nitrogen dynamics in organic and mineral soil calcareous wetlands in eastern New York. Soil Sci Soc Am J. 64: 2168-2173. doi.org/10.2136/sssaj2000.6462168x

28. Yu, X. F., Zhang, Y. X., Zou, Y. C., Zhao, H. M., Lu, X. G., \& Wang, G. P. 2011. Adsorption and desorption of ammonium in wetland soils subject to freeze-thaw cycles. Pedosphere. 21: 251-258. doi. org/10.1016/S1002-0160(11)60125-2

29. Zhang, Y. Z., Huang, S. H., Wan, D. J., Huang, Y. X., Zhou, W. J., \& Zou, Y. B. 2007. Fixed ammonium content and maximum capacity of ammonium fixation in major types of tillage soils in Hunan province, China. Agr Sci of China. 6: 466-474. doi. org/10.1016/S1671-2927(07)60071-6

30. Zhu, W. L., Cui, L. H., Ouyang, Y., Long, C. F., \& Tang, X. D. 2011. Kinetic adsorption of ammonium nitrogen by substrate materials for constructed wetlands. Pedosphere. 21: 454-463. doi.org/10.1016/ S1002-0160(11)60147-1 